\title{
Policy Contradictions and Policy Dilemma: A Case of Intermediary Money Transfer Tax (IMTT) on Business Performance in the Engineering Sector in Zimbabwe
}

\author{
Josphat Nyoni \\ Women's University in Africa, Harare, Zimbabwe \\ E-mail: jnyoni664@gmail.com \\ Tendai Vanesssa Jaravaza \\ Women's University in Africa, Harare, Zimbabwe \\ E-mail: Jaravaza.t.v@ hotmail.com
}

Matthew Mare

Women's University in Africa, Harare, Zimbabwe

E-mail: accademics2017@gmail.com

\begin{abstract}
Martin Dandira
Namibia University of Science and Technology, Namibia

E-mail: mdandira@gmail.com
\end{abstract}

Elias Kandjinga

Namibia University of Science and Technology, Namibia

E-mail: ekandjinga@nust.na

Received: January 22, 2021 Accepted: March 19, 2021 Published: March 26, 2021

doi:10.5296/ber.v11i2.18228ＵRL: https://doi.org/10.5296/ber.v11i2.18228 


\section{Abstract}

The use of tax policies to address macro-economic challenges has often led to serious other macro-economic challenges for developing countries. The purpose of this paper is to illustrate macro-economic policy dilemmas that affect developing countries when they implement tax policies to address macroeconomic challenges. The objective of the study was to examine how the 2\% Intermediary Money Transfer Tax (MTT) introduced to raise financial resources to grow the economy affected performance of companies in the engineering sector. The study was guided by the pragmatism research philosophy, used explanatory research design and a mixed research approach. Data was collected from companies in the metal fabrication and machine/equipment sub-sectors of the engineering sector. A total of 68 companies were used. The paper shows that a tax policy adopted by Zimbabwe to raise revenues for supporting economic growth and addressing several economic challenges such as poverty, unemployment and negative economic growth generated other macro-economic challenges such as declining performance of companies in the Engineering sector. Results from the study showed that 2\% IMTT had a negative an influence on business performance of companies in the engineering sector. The tax reduced profit margins, sales, and competitiveness. Conclusions from the study were that adoption of tax policies by governments, to achieve increased revenue and growth of the economy may, in the process, negatively affect some sectors of the economy. It was therefore recommended that the government analyse potential contradictions and dilemmas before implementing tax policies. Further studies of the influence of IMTT on other sectors like the small scale and informal sectors that are usually hit the hardest by government policies is recommended.

Keywords: Policy making, Taxation, Business performance, Private sector

\section{Introduction}

Zimbabwe introduced a 2\% IMTT which was levied on all transactions mediated by financial institutions and mobile money platforms. The tax was charged at $2 \%$ of the transaction value. Intermediated Money Transfer Tax (IMTT) is collected in terms of section 36G as read with the Thirtieth Schedule of Income Tax Act [Chapter 23:06]. This tax is collected by banks, building societies and mobile banking service providers. The tax policy was introduced by Zimbabwe as one of the measures which was meant to promote resource mobilisation to address various macro-economic challenges. Zimbabwe like any other global country is working towards the attainment of the Sustainable Development Goals (SDGs). In view of the SDGs, the country is making use of tax policies such as the IMTT to fund projects and programs that will increase the domestic resource mobilisation The UN advocated that developing countries mobilise domestic resources to fund and sustain the attainment of the SGDs (UN, 2015).

The recent Addis Tax Initiative also indicated that developing country must make use of tax revenue resources from their tax policies to complement technical support from developed countries. Zimbabwe therefore introduced the Intermediated Money Transfer Tax of 2 percent on all electronic transactions within Zimbabwe (the IMTT). The main motive s of introducing the IMTT was to increase tax revenue collection. The IMTT was therefore designed to 
generate additional revenue. However, it is possible that the introduction of the IMTT may have negatively affected the performance of some companies through higher cost of transacting digitally. This paper valuates the opportunity cost of the introduction of the IMTT with reference to the engineering sector in Zimbabwe.

Zimbabwe had one of the best performing and diversified engineering sector up to the 1990s when that country experienced a prolonged economic crisis. It played a critical role in the Zimbabwean economy through its support to other sectors such as agriculture, construction, and mining within the country as well as in COMESA and SADC regions of Africa (tradezimbabwe.com, 2018). The economic crisis decimated the once vibrant engineering sector in the SADC region. The economic crisis saw the closure of many firms in the sector.

The engineering and metals sector is divided into 8 major levels, namely, Level 1 (mining/raw material extraction), Level 2 (metal/mineral processing), Level 3 (metal forming), Level 4 (metal fabrication), Level 5 (machine/equipment assembly), Level 6 (product distribution), Level 7 (retailing) and Level 8 (end market). The sector commodities are classified into two categories namely the metals and metal products and the downstream engineering products. This paper evaluates the impact of the introduction of the IMTT on the performance of firms in the engineering sector in the two main sub-sectors.

\section{Literature Review}

Developing countries experience several economic challenges which require various macro-economic policy interventions. The use of tax policies to stimulate economic growth and development has raised a lot of debate among scholars with reference to their effectiveness especially in the context of developing countries. The neoclassical theory scholars argue that the use of tax policies to stimulate economic growth and development is not effective in the long run (Acosta-Ormaechea \& Yoo, 2012). They argue that the use of tax policies may have serious negative effects to other sectors of the economy despite being a reliable source of revenue for economic growth (Ecevit \& Yucel, 2016; Taufik, 2020). Endogenous growth theorist however argue that tax policies are an effective tool for generating revenues required to stimulate and support economic recovery and growth (Ahmad, Sial \& Ahmad, 2016). It is against these arguments that this paper sought to contribute to the debate on the effectiveness of tax policies in stimulating economic recovery and growth.

Arnold (2008) indicated that Governments may use direct and indirect taxes to raise revenue for supporting economic growth. A direct tax is a tax that a person or organization pays directly to the Government. Direct taxes include income taxes, company taxes, real property taxes and taxes on assets. Direct taxes are based on the ability-to-pay principle. This means that those who have more resources or earn a higher income should bear a greater tax burden. Direct taxes cannot be passed onto a different person or entity. The individual or organization upon which the tax is levied is responsible for paying it. This form of tax therefore is the most reliable sources of revenue for government ((Ecevit \& Yucel, 2016; Taufik, 2020; Ecevit $\&$ Yucel, 2016). 
Indirect taxes are taxes are imposed on a manufacturer or supplier who then passes on the tax to the consumer. The most common example of an indirect tax is the excise tax on cigarettes and alcohol, taxes on business transactions, Value Added Taxes (VAT). These taxes can however be passed on to another entity or individual(Ecevit \& Yucel, 2016; Taufik, 2020).

SchorsZeqiraj and Nimani (2015) argue that tax policies may have positive or even negative effects on the overall economic growth and hence it is critical that each tax policy be subjected to critical analysis. However, they also mention that a tax policy may leads to improved economic and social development in a country. Tax policies may however lead to depressed demand for goods and services which in turn may lead to low productivity and a reduction in investment in an economy. These factors lead to poor economic growth and development.

Barret (1963) is of the opinion that business taxes cause more inefficiency in the use of resources than individual taxes. This is because most business taxes are indirect resulting in the business not being fully aware of how much tax they are paying and the total amount of business expenditure. This implies that taxes on businesses have a greater effect on business performance than taxes on individuals. Also, taxes affect allocation of business resources and shift the effectiveness of investment. Barret (1963) cites that these taxes may in fact have a negative effect on the ultimate growth and development of the economy.

Kotlan and Machova (2013) confirmed the tax burden of the different types of taxes on corporations has a negative impact on the growth of the economy. Macek (2014) argues that the tax burden on companies will in the long run negatively affect the economic growth of the country. He therefore recommended that government spending should be reduced to reduce the need for more revenues from companies. This supports the notion that although tax revenue may benefit government spending towards productivity, major concerns are on the burden that is transmitted to companies. A reduction in productivity may be a result of heavy tax burden on companies.

Globally, financial transaction taxes have been established in countries like France and Venezuela (bnymellon.com, 2018). In France, the French Financial Transaction Tax (FFTT) is pegged at $0.2 \%$ and is levied on French shares and $0.01 \%$ levied on high-frequency-trading transactions. Investigations on the influence of adopting this tax showed that there was no notable change on share prices and consistency of the taxed market. However, trading volumes were reported to have declined immediately after the tax law was introduced (ec.europa.eu, 2012). This implies that the tax had a negative influence on capital used to enhance business performance of companies in France. The effect of this tax resulted in large French companies underperforming in the highly liquid market while smaller companies' business performance was not negatively affected. This may indicate a differential effect of Financial Transaction Tax (FFTT).

Taufik (2020) argue that the use of indirect taxes in the form of financial transaction taxes has helped several countries raise revenue to finance various programs and support the growth of industries which has led to economic growth and development. 
The literature reviewed has shown that there is no agreement among scholars on the effects of both direct and indirect taxes on economies. There are however strong sensations on the dilemma caused by taxes in terms of their potential to generate negative and positive effects at the same time.

\subsection{Tax Theories on the impact of Tax Policies}

The Optimal Tax Theory by Martinez- Vazquez, Vulovic, and Liu (2009) is based on the Artkinson- Stiglitz (1976) theory which argues that the structure of any tax determines its effect on various stakeholders. This optimal tax theory, which was first established by an economist named Frank Ramsey (1927) in the early twentieth century, addresses issues of optimal taxation. The Ramsey Tax Model was used to set different tax rates for different commodities in a way that enabled the government to minimize the tax burden while collecting enough revenue to meet the budget requirements. Usually, the indirect taxes must then be adjusted according to how steep the direct tax rates are. This leads to an optimal indirect tax structure that may not create excessive burden to companies. The relevance of this theory to this paper is that, while establishing the influence of an indirect tax on business performance, there is also need to assess its influence on other individuals (consumers) that contribute to the profitability of the businesses. This means that while a tax may not directly affect the performance of a company it may indirectly affect the company's profits if it erodes consumers' funds.

According to Kaplow (2009) there are principles that guide the study of taxation.

1. The principle of Completeness. In this principle he argues that it is not possible to study the role of one form of tax in the entire taxation system. This is so because the structure of tax is dependent on the structure of the other taxes and the revenue a tax should bring is also dependent on the revenue other taxes bring in.

2. The principle of Comprehensiveness. This principle emphasizes on a comprehensive assessment of policies that the governments use to raise revenue. This requires an assessment of the benefits and potential limitation of every tax policy.

3. The principle of Comparability. This principle emphasizes that while studying a particular tax, there is a need to assess the different effects the tax may on different stakeholders. While the 2\% IMTT tax influences was meant to raise revenue for government for economic growth, this principle cites the need to examine how the tax policy affected the performance of companies.

Based on the tax elements derived from the theory, it is possible to evaluate the potential effects of tax policies on the performance of companies

\subsection{Influence of Tax of Business Profitability}

A study by Gatsi, Gadzo, and Kportorgbi (2013) found that an increase in a business' tax base or rates has a negative effect on the financial performance of that business. Also, when revenue from sales increase, it attracts higher tax obligation, and this may also ultimately eat into profits of the business. However, the degree to which profitability is affected varies from business to business based on other factors that affect profitability. When the impact of tax on 
prices of companies do not change the selling price, the tax will eat into their profits and they will be forced to lower production to cover costs of production and remain viable. However, due to demand from consumers, companies are usually forced to produce the same level of production as before increase or introduction of tax. The resultant effect is that the extra cost of tax is then transferred to the consumers and selling prices go up.

\subsubsection{Influence of Tax on Market Share}

Gulley and Santerre (1993) who reported on how taxes influence a product or organisation's ability to control the market mention that only certain types of taxes indirectly influence market share. These are usually direct taxes like corporate and property taxes. This notion is also supported by Nesvisky (2020) who mentions that the growth inhibiting effect of the overall taxation system. Empirical research evidence has also shown that direct taxes like personal income taxes, especially for small businesses, have a negative effect on business growth and expansion.

\subsubsection{Influence of Tax on Sales Volumes}

A research by Kamar (2015) whose objective was to study the impact of government tax policies on sales revenue revealed that when taxes are increased sales revenues decline due to a decline in sales volumes which affect recapitalization of the business. When tax rates are low consumers are more mobile with their purchasing behaviours and sales volumes are pushed regardless of geographic location. However, when taxes increase and cause prices of products and services to also increase consumers tend to pay particular attention to other issues like how far a store is from them and the cost in energy, money and time associated with purchase of the product, shipping charges, product category and specification, and other sales and marketing efforts provided by companies. Therefore, even though demand does not necessarily decrease, sales volumes change according to overall cost associated with purchase (Anderson, Fong, Simester, and Tucker, 2009).

\subsubsection{Influence of Tax on Return on Investments}

Muzurura and Sikwila (2018) found that taxation revenues are used by governments to enhance public infrastructure that facilitates the ease of doing business by companies. This then contributes to higher levels of productivity and the realisation of higher return on investments as well as foreign direct investments. However, in the case of Zimbabwe the tax revenues are mainly used for non-productive expenditure such as salaries (Muzurura and Sikwila, 2018), leading to lower investment growth, lower productivity, and lower return on investments. While taxes subsequently affect the return on investments there are other factors that may distort the value of return on investments such as the rate of return and the economic depreciation (Oloidi, 2014)

\subsection{Empirical Reviews}

Ocheni and Gemade (2015) studies the effects of multiple taxes on business performance. The aim of their research was to first establish if there is a correlation between multiple taxes and the survival of businesses and secondly to assess whether the size of businesses and their 
ability to meet their tax obligation affects their survival. The theories guiding their study were the theories on business growth. Analysis of the data collected showed that multiple taxes have a negative effect on growth and survival of businesses, and that the size of the businesses and their ability to pay taxes have no significance on the survival of the business. They therefore concluded that multiple taxations may lead to negative effects on business viability.

In a report by Ferracuti (2018), in Uganda, protesters took to the streets of Kampala over a $1 \%$ tax on all mobile transfers and transactions. Research showed that soon after the government passed this amendment act nearly $50 \%$ of mobile users had either transacted less or stopped transacting on mobile completely. This caused the government to review its decision and send a new recommendation to parliament to instead charge $0.5 \%$ tax on withdrawals only. While it has contributed to about $7.2 \%$ of Tanzania's total tax revenue the report notes that the transaction tax has had a negative influence on transaction volumes as well as rate of digitization which has decreased business efficiency and profitability of most companies.

\section{Research Methodology}

\subsection{Research Philosophy}

This research adopted the pragmatism approach. The philosophy enabled the application of quantitative and qualitative approaches in this study.

\subsection{Research Design}

This research adopted an explanatory research design. This design attempts to help understand the cause and effects relationship between the Intermediated Money Transfer Tax (IMTT and performance indicators of companies in the engineering sector.

\subsection{Population}

In this research, a sample of 395 respondents from 68 engineering companies in Zimbabwe was used. The study used the stratified sampling technique to obtain the sample

\subsection{Data Collection}

Data was collected using survey and interviews. A questionnaire was developed and administered. The reliability of the questionnaire was tested, and the results are presented. Data was tested for normality before regression was done.

\subsection{Ethical Considerations}

The ethical issues considered for this research included informed consent, confidentiality, permission, integrity and respect for people's rights and nobility: While conducting this research, the researcher was aware of respondent's basic human rights and right to express themselves in the most naturalistic way. 


\section{Macrothink}

\section{Results and Discussions}

\subsection{Test of the Normality of Data}

Skewedness is statistical measure of the asymmetry of the distribution of data about its mean. It indicates the amount and direction of the skew that is, departure from the horizontal asymmetry (Westfall, 2014). A general guideline for skewness is that if the number is greater than +1 or lower than -1 , this is an indication of a substantially skewed distribution. (Westfall, 2014). In this study, as indicated in table 1 skewedness ranged from -0.3 up to more than +1 which is relatively indicating a normal distribution.

Table 1. Results of the normality test

\begin{tabular}{|l|l|}
\hline Variables & Skewness \\
\hline Profitability & 1.200781352 \\
\hline Market Share & $\mathbf{- 1 . 0 5 3 8 4 3 6 0 3}$ \\
\hline Sales Volume & $\mathbf{- 0 . 3 9 2 2 8 1 0 3 9}$ \\
\hline Return on Investments & 1.29606937 \\
\hline
\end{tabular}

Source: Field Data

\subsection{Reliability Test Results}

Cronbach's alpha was used to test whether the instrument had internal consistency. Table 2 indicates the results of the reliability tests conducted in this study.

Table 2. Reliability test results

\begin{tabular}{|l|l|}
\hline Variables & Cronbach alpha \\
\hline Profitability & 0.96927 \\
\hline Market Share & 0.976377 \\
\hline Sales Volume & 0.939485 \\
\hline Return on Investments & 0.952373 \\
\hline
\end{tabular}

Source: Field Data

The Cronbach alpha for the variables ranged from 0.939485 to 0.977377 which indicates that there is internal consistence for questions within each variable. It also shows that the instruments measured the constructs in a consistent way given that the values are greater than 0.7 (Hair et al., 2017,).

\section{Correlation and Regression Analysis of the Influence of IMTT on the Performance of Companies in the Engineering Sector}

The first section presents the correlation analysis of the relationship between IMTT and four performance indicators of companies in the engineering sector. 
5.1 Correlation Analysis of the Relationship between IMTT and Four Performance Indicators of Companies in the Engineering Sector.

Table 3 shows the correlation results of the relationship between IMTT and four performance indicators of companies in the engineering sector. The four performance indicators are profitability, market share, sales growth and return on investment which are the dependent variables. The correlation analysis was used to identify the degree to which IMTT affected each indicator.

Table 3. Correlation analysis of the relationship between IMTT and performance of companies

\begin{tabular}{|l|l|l|l|l|}
\hline & Profitability & $\begin{array}{l}\text { Market } \\
\text { Share }\end{array}$ & $\begin{array}{l}\text { Sales } \\
\text { Volume }\end{array}$ & $\begin{array}{l}\text { Return on } \\
\text { Investments }\end{array}$ \\
\hline Correlation Coefficient Values & -0.900 & -0.103 & -0.300 & -0.900 \\
\hline
\end{tabular}

According to Table 3 the correlation value of -0.900 shows that there is a strong negative linear association between IMTT and profitability.

According to Table 3 the correlation value of -0.103 shows that there is a weak negative linear association between IMTT and market share.

According to Table 3, the correlation value of -0.300 shows that there is a weak negative linear association between IMTT and sales volumes.

According to Table 3 the correlation value of -0.900 shows that there is a strong negative linear association between IMTT and Return on Investments.

5.2 Regression Analysis Results of the Relationship between IMTT and Four Performance Indicators of Companies in the Engineering Sector

In addition to the correlation, a regression analysis was done to determine the nature and scope of the relationship between IMTT and four performance indicators of companies in the engineering sector. Regression analysis was used to infer causal relationships between the independent variable (IMTT) and four dependent variables (profitability, market share, sales growth and return on investment). The results of the regression are presented in Table 4.

Table 4. Regression results

\begin{tabular}{|l|l|l|}
\hline & Beta & p-level \\
\hline Profitability & -4.6385 & 0.0000 \\
\hline Market share & -0.1283 & 0.0000 \\
\hline Sales growth & -0.2351 & 0.00067 \\
\hline Return on investment & -3.7125 & 0.0000 \\
\hline
\end{tabular}

Source: Field Data 
Table 4 indicates that the IMTT had a significant and negative influence on profitability because $(B=-4.6385, \mathrm{p}<0.05)$. A unit increase in IMTT caused profitability to decrease by about 4 times. Therefore, the adoption of the IMTT had a significant and strong negative influence on profitability given the higher beta value of 4.6385. The study discovered that IMTT has had a strong negative influence on the profitability of businesses where after IMTT was increased there was an increase in cost of sales, low levels of business efficiency, increase in cost of operations, and a subsequent negative influence in the net income of the business. The data collected corresponds with research from the literature review that when taxes that influence business activities increase the cost of operations increase and the profitability of the business reduces (Gatsi, Gadzo and Kportorgbi, 2013).

The results in Table 4 shows that the IMTT had a significant and negative influence on market share because $(\mathrm{B}=-0.1283, \mathrm{p}<0.05)$. The influence is however weak given the low beta vale of 0.1283 . Therefore, the adoption of the IMTT had a significant negative but weak influence on market share. This implies that the expansion of a business into new geographic territories, change in customer acquisition levels, and an increase in the level of competition in the sector, though negatively affected, were not significant. This corresponds with the literature review from previous studies that concluded that only certain types of taxes affect market share of businesses and these taxes are mostly direct taxes (Gulley and Santerre, 1993). IMTT is an indirect tax and therefore its influence on market share, if present, is not significant.

Table 4 indicates that the IMTT had a significant and negative influence on sales growth because $(\mathrm{B}=--0.2351, \mathrm{p}<0.05)$. The influence is however weak given the low beta vale of 0.2351. Therefore, the adoption of the IMTT had a significant negative but weak influence on sales growth. Therefore, the adoption of the IMTT had a significant but weak negative influence on sales growth given the low beta value of 0.2351 . The results obtained are not in line with findings from the literature review that suggests that increasing taxes, both direct and indirect, causes a decrease in sales volumes (Kamar, 2015). This may be a new finding with respect to the influence of the indirect on sales volumes. This may show that sales volumes may be more affected by other factors in the business environment ta $\mathrm{n}$ taxes.

The results in Table 4 indicates that the IMTT had a significant and negative influence on the return on investment because $(B=-3.7125, p<0.05)$. A unit increase in IMTT caused the return on investment to decrease by about 3 times. Therefore, the adoption of the IMTT had a significant and strong negative influence on the return on investment given the higher beta value of 3.7125. This finding is in line with views raised in the existing literature review where it has been indicated that indicate that indirect taxes tend to reduce the value of return on investments (Harris and Kemsley, 1999). The findings also shows that if taxes negatively affect profitability, this may in turn affect return on investment activities.

\section{Conclusion}

It can be concluded that the policy of IMTT negatively affect the performance of companies in the engineering sector. The strong and negative influence of the IMTT on profitability and return on investment implies that the viability of such companies may be threatened in the 
long run. This implies that tax policies developed to stimulate the economy may in turn hurt some sectors of the economy leading to a negative influence on the economy thereby generating a dilemma for policy makers. The Zimbabwean Tax policy in the form of the IMTT therefore has generated a policy dilemma for the country through its negative influence on the profitability and return on investment on some companies. The question then that creates challenges and dilemma for policy makers is can they allow the IMTT policy to continue despite its negative influence on the engineering sector which is critical to the transformation of the economy.

\section{Recommendations}

Based on the research findings of this study it is therefore recommended that Governments introduce another policy to cushion companies that have been negatively affected by the IMTT policy. It is also recommended that the IMTT be substituted by other revenue generating programs which are not a threat to the viability of the business sector. While the need for revenue by government remain critical it is recommended that a cost benefit analysis be adopted to determine the life span of the IMTT.

\section{Recommendation for Further Studies}

It is recommended that an evaluation of the influence of the IMTT on the performance of companies be extended to other sectors such the manufacturing sector and the mining sector

\section{Acknowledgement}

Women's University in Africa is acknowledged for facilitating this study.

\section{References}

Acosta-Ormaechea, S., \& Yoo, Y., (2012). Tax Composition and Growth: A Broad Cross-Country Perspective. IMF Working Paper 257.

https://doi.org/10.5089/9781616355678.001

African Development Bank. (2019). Zimbabwe Infrastructure Report for 2019. [Online] Available: https://www.afdb.org/fileadmin/uploads/afdb/Documents/Project-and-Operations/ Zimbabwe_Infrastructure_Report_2019_-_AfDB.pdf

Ahmad, S., Sial, M. H., \& Ahmad, N. (2016). Taxes and Economic Growth: An Empirical Analysis of Pakistan. European Journal of Business and Social Sciences, 5(2), 16-29. https://doi.org/10.21859/eulawrev-08062

Anderson, E. T., Fong, N. M., Simester, D. I., \& Tucker, C. E. (2009). How Sales Tax Affects Consumer and Firm Behaviour: The Role of Search on the Internet. Journal of Marketing Research, Vol. XLVI. https://doi.org/10.2139/ssrn.986847

Arnold, J. (2008). Do Tax Structure Affect Aggregate Economic Growth? Empirical Evidence from a Panel of OECD Countries. OECD Economics Department Working Paper 643. OECD Paris.

Atkinson, A. B., \& Stiglitz, J. E. (1976). The Design of Tax Structure: Direct versus Indirect 


\section{Macrothink}

Business and Economic Research ISSN 2162-4860 2021, Vol. 11, No. 2

Taxation. Journal of Public Economics, 6, 55-75.

https://doi.org/10.1016/0047-2727(76)90041-4

Bankbazaar.com. (2020). Indirect Taxes. [Online] Available:

https://www.bankbazaar.com/tax/indirect-tax.html

Barret A. L. (1963). Some Effects of Taxes on Business and Financial Organisations. The American Journal of Economics and Sociology, 22(3), 397-407.

https://doi.org/10.1111/j.1536-7150.1963.tb00897.x

Bnymellon.com. (2018). [Online] Available:

https://www.bnymellon.com/emea/en/_locale-assets/pdf/our-thinking/ftt-globalperspective-br ochure-03-2018.pdf

Business in Ancient Greece. [Online] Available:

https://onlinebusiness.northeastern.edu/masters-in-finance-msf/business-in-ancient-greece/

Businesstimes.co.zw. (2019). "Controversial” Taxes Drive Government Revenue. [Online] Available: https://businesstimes.co.zw/controversial-taxes-drive-government-revenue/

Characteristics of Qualitative Observational Research. [Online] Available:

https://writing.colostate.edu/guides/page.cfm?pageid=1352\& guideid=63

Ec.europa.eu. (2012). [Online] Available:

ttps://ec.europa.eu/taxation_customs/sites/taxation/files/docs/body/effect_french_ftt.pdf

Ecevit, E., \& Yucel, A. G. (2016). Are Some Taxes Better Than Others for Economic Growth? An ARDL Approach of Turkey. The Empirical Economics Letters, 15(11), 1129-1136.

Engineering Council of Zimbabwe. [Online] Available:

https://www.ecz.co.zw/index.php/firms

Ferracuti, A. (2018). Understanding the Consequences of Mobile Money Taxes in Uganda. [Online] Available: ttps://www.uncdf.org/article/3892/understanding-the-consequences-of-mo bile-money-taxes-in-uganda

Gatsi, J. G., Gadzo, S. G., \& Kportorgbi, H. K. (2013). The Effect of Corporate Income Tax on Financial Performance of Listed Manufacturing Firms in Ghana. Research Journal of Finance and Accounting, 5(15).

Gulley, O. D., \& Santerre, R. E. (1993). The Effect of Tax Exemption on the Market Share of Non-Profit Hospitals. National Tax Journal, 46(4), 477-486.

https://doi.org/10.1086/NTJ41789040

Harris, T. S., \& Kemsley, D. (1999). Dividend Taxation in Firm Valuation: new evidence, Journal of Accounting Research, 37, 275-291. https://doi.org/10.2307/2491410

Hogan, W. (1851). Advantages and Disadvantages of Indirect Taxation and a Scheme for Direct Taxation which would be Equitable and Combine the Advantages of an Indirect Tax. [Online] Available: http://www.tara.tcd.ie/bitstream/handle/2262/21440/jssisiVolII1_7.pdf?se 
quence $=1 \&$ isAllowed $=\mathrm{y}$

Kamar, I. K. (2015). Effect of Government Taxation Policy on Sales Revenue of SME in Uasin Gishu County, Kenya. International Journal of Business Management Invention, 4(2), $29-40$.

Kotlan, I., \& Machova, Z. (2013). The Impact of the Tax Burden on the Living Standard in OECD Countries. [Online] Available:

https://www.sav.sk/journals/uploads/0621141609\%2013\%20Kotlan-Machova-RS.pdf

Macek, R. (2014). Impact of Taxation on Economic Growth: Case of OECD Countries. Review of Economic Perspectives, 14(4), 309-328. https://doi.org/10.1515/revecp-2015-0002

Martinez- Vazquez, J., Vulovic, V., \& Liu, Y. (2009). Direct Versus Indirect Taxation: Trends, Theory and Economic Significance. International Studies Program Working Paper 09-11. [Online] Available: https://www.researchgate.net/publication/46455664_Direct_versus_Indir ect_Taxation_Trends_Theory_and_Economic_Significance

Mazorodze, B. (2018). Government Expenditure and Economic Growth in Zimbabwe. African Journal of Business and Economic Research (AJBER), 13(2), 183-202.

https://doi.org/10.31920/1750-4562/2018/v13n2a9

Merrium-Webster.com. [Online] Available:

https://www.merriam-webster.com/dictionary/population

Muzurura, J., \& Sikwila, N. (2018). Taxation, Private Fixed Domestic Investment Behaviour, and Zimbabwe's Economic Growth. American Journal of Humanities and Social Sciences Research (AJHSSR), 2(5), 26-39.

Ocheni, S. I., \& Gemade, T. I. (2015). Effects of Multiple Taxation on the Performance of Small and Medium Scale Business Enterprises in Benue State. International Journal of Academic Research in Business and Social Sciences, 5(3).

https://doi.org/10.6007/IJARBSS/v5-i3/1528

Oloidi, G. A. (2014). Company Income Tax and Investment Decisions: A Behavioural Approach. IOSR Journal of Business Management, 16(7), 11-19.

https://doi.org/10.9790/487X-16751119

Rajibkumar, S. (2019). Profit Theory 1. Planned Economy and Growth. pp. 317. [Online] Available: https://www.researchgate.net/publication/335023002_Profit_Theory_1

Saungweme, T., \& Matandare, M. A. (2014). Agricultural Expenditure and Economic Performance in Zimbabwe (1980- 2005). International Journal of Economic Research, 5(5), 50-59.

Statistica.com. (2020). [Online] Available: https://www.statista.com/statistics/455310/share-o f-economic-sectors-in-the-gdp-in-zimbabwe/

Stoilova, D., \& Patonov, N. (2012). An Empirical Evidence on The Impact of Taxation on Economy Growth in the European Union. [Online] Available: 
file://C:/Users/user/Downloads/Dialnet-AnEmpiricalEvidenceForTheImpactOfTaxationOnE conomy-4788887\%20(1).pdf

Taufik, A. H. (2020). Direct Versus Indirect Taxes: Impact on Economic Growth and Total Tax Revenue. International Journal of Financial Research, 11(2).

https://doi.org/10.5430/ijfr.v11n2p146

The Business Times. (2019). [Online] Available:

https://businesstimes.co.zw/govts-2-tax-rakes-in-millions/

Theory of Indirect Taxation and Fiscal Federalism. [Online] Available:

https://shodhganga.inflibnet.ac.in/bitstream/10603/52848/13/13_chapter\%203.pdf

Tradezimbabwe.com. (2018). [Online] Available:

https://www.tradezimbabwe.com/buying-from-zimbabwe-2/sector-briefs/

Tsaurai, K. (2014). Military Expenditure and the Economy of Zimbabwe. Journal of Governance and regulation, 3(2), 65-73. https://doi.org/10.22495/jgr_v3_i2_c1_p6

www.economicsonline.co.uk, Indirect Taxes- subsidies. [Online] Available:

https://www.economicsonline.co.uk/Competitive_markets/Indirect_taxes_and_subsidies.html

Yeh, C., \& Chang, T. (2013). A General Theory of Market Competition- M Theory. International Conference on Applied Social Science Research.

https://doi.org/10.2991/icassr.2013.63

Zajonc, R., \& Markus, H. (1982). Affective and cognitive factors in preferences. Journal of Consumer Research, 9(2), 123-131. https://doi.org/10.1086/208905

Zhou, G., \& Madhikeni, A. (2013). Systems, Processes and Challenges of Public Revenue Collection in Zimbabwe. American International Journal of Contemporary Research, 3(2), 49-60.

Zimbabwe Revenue Authority (2019). Revenue Performance Report for the Quarter ended 31 December 2019. [Online] Available:

https://www.zimra.co.zw/downloads/category/12-revenue-perfomance-reports

Zindiye, S., Chiliya, N., \& Masocha, R. (2012). The Impact of Government and other Institutions Support on Performance of Small Medium Enterprises in the Manufacturing Sector in Harare, Zimbabwe. International Journal of Business Management and economic Research, 3(6), 655-667. https://doi.org/10.5897/AJBM11.2387

\section{Copyright Disclaimer}

Copyright for this article is retained by the author(s), with first publication rights granted to the journal.

This is an open-access article distributed under the terms and conditions of the Creative Commons Attribution license (http://creativecommons.org/licenses/by/4.0/). 